\title{
Incest and inbreeding: issues of criminal liability
}

\author{
A. A. Bimbinov* \\ Kutafin Moscow State Law University (MSAL), Moscow, Russia
}

\begin{abstract}
This study seeks answers to the most common issues on incest criminality. It is supposed to resolve issues on the existence of a public danger of incest, on the possibility of establishing criminal liability for incest in Russian legislation, as well as on the admissibility and relevance of the corresponding corpus delicti. These issues are considered on the basis of the study of modern scientific works of Russian and foreign authors, the analysis of domestic and foreign legislation and the comparison of the results with the social and biological aspects of human life. The results of the study may have both scientific and applied, as well as methodological relevance, including the possibility of using them in new scientific research
\end{abstract}

\section{Introduction}

Before considering criminal legal issues related to incest, it is necessary to determine the content of this concept for the purposes of this study. Once incest was understood as any form of adultery, now incest, as a rule, is called sexual activity between relatives. However, there are no clear and unambiguous characteristics of this category either in science or in domestic legislation.

Incest refers to sexual intercourse that may lead to "inbreeding", as well as any sexual relationship between blood relatives or persons who are not relatives in the literal sense of the word, for example, between a child and a guardian or a permanent sexual partner of a mother or a father [1]. Sexual relations between people of any degree of kinship, both voluntary and violent, are considered incestuous [2]. Incest can only be between adult relatives and involving juveniles and minors in sexual relations [3, p. 104]. Incest includes sexual relations between both sexes and same-sex relatives [4].

Such different approaches to understanding incest are caused by differences in society, culture and legal jurisdiction. Incest has long been taboo and has been the subject of myths, legends and literature (for example, Oedipus - the tragedy of Sophocles). A large number of sources explain why incest should be banned. The reasons for the ban range from psychodynamic traditions to genetic, sociological, religious and historical needs in relations between kinship systems [5]. Furthermore, limitations of incestuous relationships may be related to specific relationships between individuals, age difference, degree of sexual activity, consent, duration of sexual relationship, and norms of sexual behavior [6].

However, it should be noted that the literature does not refer to any universal reason for banning incest. Basically, the authors build their reasoning around one or more specific forms of incest manifestation. Thus, Stuart Green writes that the most common form of incest is the sexual relationship between an adult and a child, which should be regarded as sexual abuse of children (rape) [7]. Peter Choate and Radha Sharan note a high incidence of pathological genes in offspring. If incest leads to pregnancy and childbirth, the authors write that the risk of genetic defects in such offspring is higher than that of offspring from unrelated couples - especially if both partners have a recessive gene in incest [8]. Nevertheless, there is no sufficient evidence of largescale hereditary pathologies of incest. The prevalence of incest is very different and depends on the particular society and its cultural characteristics. In Western countries, incest cases are detected in criminal proceedings in cases of sexual violence, but its true prevalence is unknown. In the Middle East and the Indian subcontinent, according to some reports, up to $50 \%$ of marriages are concluded between cousins and uncles and nieces, which, however, does not seem to have serious adverse genetic effects on the health of citizens living in these territories [8].

Thus, there are two generalized approaches to the definition of incest that can entail criminal liability.

The first involves sexual acts between a parent (adoptive parent, guardian, etc.) and a minor child. This form of incest is the most common among all established cases that have undergone scientific study. Ali Yildirim and co-authors confirm that the sexual relationship between a father and a daughter is the most common version of incest, in second place is the relations between a brother and a sister [9]. This type of incest entails criminal liability in most states if a child has not reached the age of consent or puberty established by the national legislation, as well as if there has been violence, including mental violence, or abuse by an adult, including the use of the helpless state of the child.

\footnotetext{
Corresponding author: bimbinov@yandex.ru
} 
The Criminal Code of the Russian Federation provides for liability for these acts under Parts 3 to 5 of Articles 131 and 132 for the rape of a minor or the commission of sexual assault against him; Article 133, Paragraph 2 - for coercion of a minor to acts of a sexual nature by blackmail, threatening to destroy, damage or seize property or using his material or other dependence; Articles 134-135 - for acts of a sexual nature with a person under the age of sixteen or indecent acts against him - using in all the listed cases paragraph "p" of Part 1 of Article 63 (commission of a crime against a juvenile (minor) by a parent or other person entrusted by law with the duties of raising a juvenile (minor) as well as a teacher or other employee of an educational organization, medical organization, social service organization or other organization obliged to supervise a juvenile (minor) as a circumstances aggravating punishment.

According to the second approach, incest is sexual relations between adult relatives capable of reproduction. As a rule, in this case we are talking about adult children (brother and sister), close relatives and other persons connected by blood ties with each other [7].

The Oxford Public Health Dictionary defines incest as a sexual activity between close blood relatives with the possibility of pregnancy, i.e. for example, between brothers and sisters, a diclinous parent and a child, an uncle and a niece, an aunt and a nephew. If such sexual activity is voluntary, is not a consequence of compulsion or coercion on someone else, then under the current Russian law it is not criminal. It is in this sense (capable of conceiving a blood-related non-violent sexual relations between adults) that incest will be considered in relation to solving the issues on the presence of its public danger, the possibility of establishing criminal liability for it, as well as the admissibility and relevance of the corresponding corpus delicti under the Criminal Code of the Russian Federation.

\section{Results and Discussion}

\subsection{Danger of incest}

As already noted, the prohibition of incest and liability for its violation may be explained by a variety of reasons. Anthropologist George Peter Murdoch, who tried to compile an exhaustive list of human behaviors that were common to all people at all times, was struck by the prevalence of the ban on incest. According to the author, no society (except Roman Egypt and royal marriages between certain dynasties) has ever approved of sexual relations between parents and their offspring or between siblings. For most of human history, incest has been universally criminalized. Today, it is criminalized even in leading states by the so-called freedom index (for example, the United States of America, Canada or the Federal Republic of Germany). In those countries where incest does not entail criminal liability, it is morally condemned [11]. The reason why other forms of incest (with the exception of blood-related non-violent incest between adults with fertility) are prosecuted by law is related to religious, and subsequently to social prerequisites. The main reasons for the prohibition of incest (as understood for the purposes of the present study) are inbreeding (crossing of closely related forms within the same population), inbred depression (reduced bioavailability) and possible hereditary pathology.

The human body, like any other diploid organism, receives each gene in two copies (alleles) - from a father and from a mother. If these alleles differ, then the individual is called heterozygous, and if they do not differ, then homozygous. In inbreeding, parents are related, so they have many identical alleles, as a result of which homozygosis increases with each generation. With closely related crossbreeding (or self-pollination in plants), inbred depression may occur: a decrease in the yield of plant crops, degeneration of animals, occurrence of anomalies and ugliness, including in human offspring. This is due to homozygosis on harmful recessive alleles.

The degree of homozygosis, i.e. the degree of inbreeding, is determined by the Wright formula ( $\mathrm{S}$. Wright):

$\mathrm{Fx}=\sum(1 / 2) \mathrm{n}+\mathrm{n} 1-1$,

where $F x$ - inbreeding coefficient, $n$ - number of generations from a common maternal ancestor, $n 1$ number of generations from a common paternal ancestor. Thus, offspring from a father with a daughter or a mother with a son in $25 \%$ of cases can be a carrier of recessive alleles, from a brother with a sister $-25 \%$, from a grandfather with a granddaughter $-12.5 \%$, from a cousin with a sister $-12.5 \%$. Certain diseases are common among such populations with high levels of inbreeding. In Lebanon, Saudi Arabia, Egypt and Israel, offspring of blood relatives have an increased risk of congenital malformations, congenital heart defects, congenital hydrocephalus and neural tube defects. Among inbred children in Palestine and Lebanon, there is a link between blood kinship and reported cases of hare lip/cleft palate.

Most Russians know about the possible consequences of incest from a school biology course (when studying the Mendel's laws) using the example of smooth and wrinkled forms of peas. Adaptation and primitivization (it seems that primitivization and explanation using the known examples make it possible to better understand the essence of an unknown phenomenon) of the incest mechanism, for example, with a pea, can explain the potential danger of this sexual relationship. 


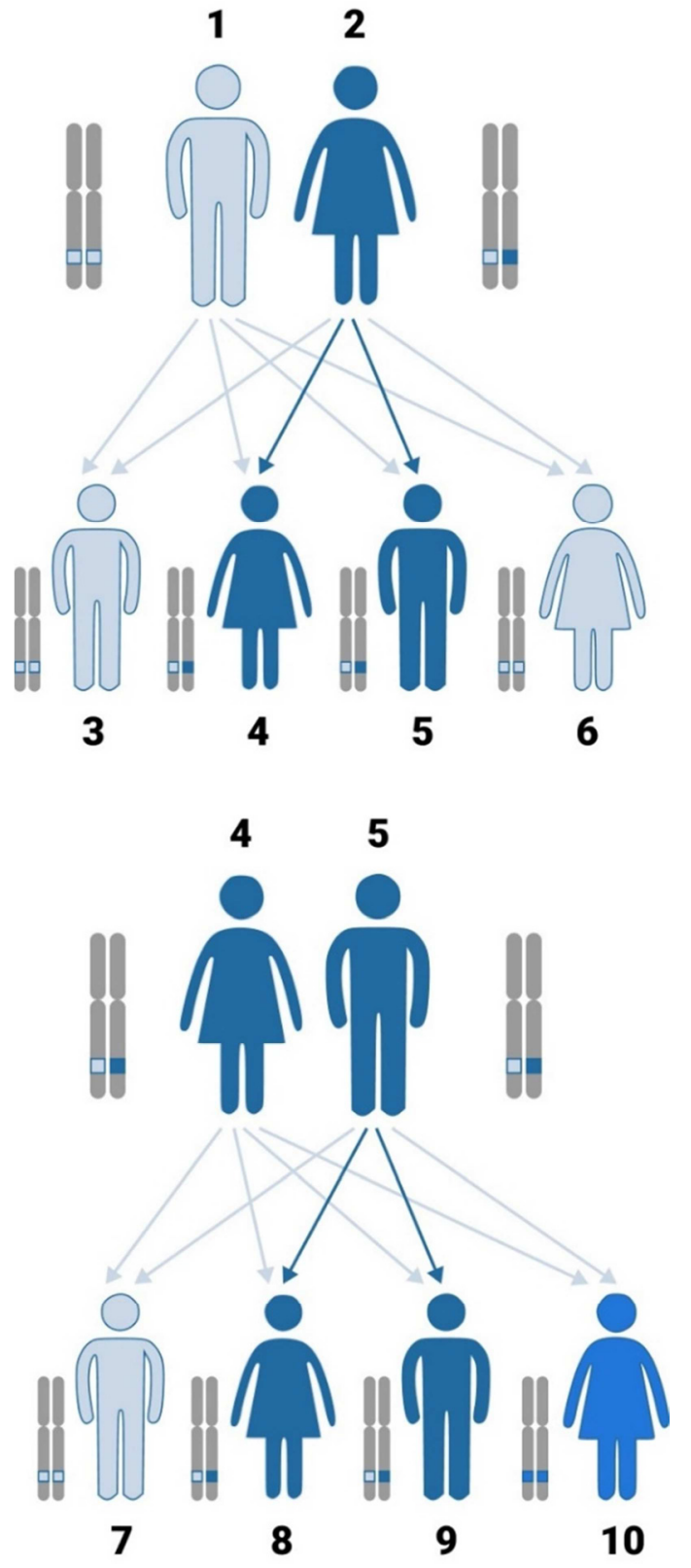

Figure 1. Mechanism of offspring formation with a set of recessive genes.

Figure 1 shows the mechanism of offspring formation with a set of recessive genes, which, inter alia, is the cause of serious pathologies.

Person No. 2 contains a recessive allele, which is able to ensure the manifestation of a definable sign (pathology) if it is in a homozygous state.

Offspring from person No. 2 and person No. 1 are recognized as healthy, but persons No. 4 and No. 5 contain a recessive gene that does not appear due to dominant genes. However, when forming offspring from these persons with a recessive gene (No. 4 and 5), in $25 \%$ of cases a person is born with a full set of recessive alleles that cause hereditary pathology (person No. 10).

The above allows concluding that blood-related closely related non-violent incest between adults poses a danger to the health (probably the population), since in
$25 \%$ of cases offspring from such a sexual relationship may have a hereditary pathology.

\subsection{Possibility of establishing criminal liability}

Criminal liability for incest is quite common. Below is a table with a far incomplete list of states from different continents establishing liability for blood-related closely related non-violent incest between adults. The second column shows the forms of incestuous relations. An indication of the relations between direct ancestors and descendants implies a relationship between relatives in a direct ascending or descending line, for example, a father and a daughter or a mother and a son. The third column describes the punishment prescribed by the national law for the forms of incest indicated in the second column.

Table 1. Some states that criminalize incest 


\begin{tabular}{|c|c|c|}
\hline $\begin{array}{l}\text { Countr } \\
\mathbf{y}\end{array}$ & Prohibited forms of incestuous relations & Punishment \\
\hline Austria & $\begin{array}{l}\text { - Direct ancestors and descendants } \\
\text { - Full brothers and sisters }\end{array}$ & Up to 3 years imprisonment \\
\hline Canada & $\begin{array}{l}\text { - Child / parent or grandson / grandfather or } \\
\text { grandmother } \\
\text { - Full brothers and sisters and stepbrothers and } \\
\text { stepsisters }\end{array}$ & Up to 14 years imprisonment \\
\hline Chile & $\begin{array}{l}\text { - Direct ancestors and descendants } \\
\text { - } \quad \text { Full brothers and sisters }\end{array}$ & Up to 1 year imprisonment \\
\hline Czech Republic & $\begin{array}{l}\text { - } \text { Direct ancestors and descendants } \\
\text { - } \text { Brothers and Sisters } \\
\text { - } \quad \text { Full and half-blood relatives }\end{array}$ & Up to 3 years imprisonment \\
\hline Denmark & $\begin{array}{l}\text { - Direct ancestors and descendants } \\
\text { - Full brothers and sisters }\end{array}$ & $\begin{array}{l}\text { - Up to } 6 \text { years imprisonment (direct line) } \\
\text { - Up to } 2 \text { years imprisonment (brothers and sisters) }\end{array}$ \\
\hline Estonia & $\begin{array}{l}\text { - Grandparents, parents, children or grandchildren } \\
\text { - Full and half-blood relatives }\end{array}$ & From 2 to 8 years imprisonment \\
\hline Greece & $\begin{array}{l}\text { - Direct ancestors and descendants } \\
\text { - Full and half-blood brothers and sisters }\end{array}$ & $\begin{array}{l}\text { - More than } 10 \text { years imprisonment for an ascending } \\
\text { relative if the descending relative is under } 15 \text { years of } \\
\text { age, imprisonment if } 15 \text { but not } 18 \text { years of age and up } \\
\text { to } 2 \text { years imprisonment if } 18 \text { years or older } \\
\text { - Up to } 2 \text { years imprisonment if brothers and sisters or } \\
\text { stepbrothers and stepsisters }\end{array}$ \\
\hline Iceland & $\begin{array}{l}\text { - Direct ancestors and descendants } \\
\text { - Full and half-blood brothers and sisters }\end{array}$ & $\begin{array}{l}\text { - Up to } 8 \text { years imprisonment for an ascending relative } \\
\text { - Up to } 12 \text { years if the relative is between } 15 \text { and } 17 \\
\text { years of age } \\
\text { - Up to } 4 \text { years imprisonment for brothers and sisters }\end{array}$ \\
\hline Ireland & $\begin{array}{l}\text { - Granddaughter, daughter, mother, sister or } \\
\text { stepsister (man) } \\
\text { - Grandfather, father, son, brother or stepbrother } \\
\text { (woman) }\end{array}$ & - Up to 10 years imprisonment (men and women) \\
\hline Iran & $\begin{array}{l}\text { - Blood relatives prohibited by religious law } \\
\text { - Stepmother }\end{array}$ & Capital punishment \\
\hline New Zealand & $\begin{array}{l}\text { - Direct ancestors and descendants } \\
\text { - Full brothers and sisters and stepbrothers and } \\
\text { stepsisters }\end{array}$ & Up to 10 years imprisonment \\
\hline Norway & $\begin{array}{l}\text { - Direct ancestors and descendants } \\
\text { - Brothers and sisters } \\
\text { - Step family }\end{array}$ & Up to 5 years imprisonment \\
\hline Poland & $\begin{array}{l}\text { - Direct ancestors and descendants } \\
\text { - Guardian or ward } \\
\text { - Full brothers and sisters and stepbrothers and } \\
\text { stepsisters }\end{array}$ & From 3 months to 5 years imprisonment \\
\hline $\begin{array}{l}\text { South Africa } \\
\text { (in particular, } \\
\text { Republic of } \\
\text { South Africa) }\end{array}$ & $\begin{array}{l}\text { - Direct ancestors and descendants } \\
\text { - Within the first degree of blood relation } \\
\text { - Within the first degree of kinship } \\
\text { - Adoptive parent/child }\end{array}$ & $\begin{array}{l}\text { Up to } 3 \text { years imprisonment and a fine } \\
\text { (not punished if both minors) }\end{array}$ \\
\hline Switzerland & $\begin{array}{l}\text { - Direct ancestors and descendants } \\
\text { - Full brothers and sisters }\end{array}$ & Up to 3 years imprisonment \\
\hline Sudan & $\begin{array}{l}\text { - Direct ancestors and descendants or their } \\
\text { spouses } \\
\text { - Sister, brother or their children, aunt or uncle } \\
\text { - Same-sex relations are always prohibited }\end{array}$ & $\begin{array}{l}\text { - Capital punishment in same-sex relations; } \\
\text { - Additional punishment up to } 5 \text { years imprisonment } \\
\text { otherwise }\end{array}$ \\
\hline
\end{tabular}




\begin{tabular}{|c|l|l|}
\hline $\begin{array}{c}\text { Countr } \\
\mathbf{y}\end{array}$ & \multicolumn{1}{|c|}{ Prohibited forms of incestuous relations } & \multicolumn{1}{c|}{ Punishment } \\
\hline $\begin{array}{c}\text { United Arab } \\
\text { Emirates }\end{array}$ & Blood relatives prohibited by religious law & Capital punishment \\
\hline Great Britain & $\begin{array}{l}\bullet \quad \text { Parent, grandparents, child, grandson } \\
\bullet \quad \text { Unother, sister, stepbrother, stepsister }\end{array}$ & $\begin{array}{l}\text { Up to 2 years imprisonment for sex between adult } \\
\text { relatives (with penetration) } \\
\bullet \text { Up to 14 years imprisonment for sexual relations } \\
\text { with a child family member }\end{array}$ \\
\hline
\end{tabular}

The probability of hereditary pathology, as well as potential harm to public morals and the interests of the family and minors, allow concluding that it is possible to establish incest liability in the Russian criminal law (as understood for the purposes of this study).

\subsection{Permissibility and relevance of incest components according to the Criminal Code of the Russian Federation}

The experience of the states listed in the table shows that in most of them the rule of liability for incest is located in the chapter (section) on crimes against the interests of the family. Meanwhile, the certainty of the object of the criminal law protection (as a criterion for classifying crimes according to the chapters of the Criminal Code of the Russian Federation) is not obvious. Considering the manner in which the said act was committed, and also that the danger of incest consists in the possibility of hereditary pathology and causing harm to public morals in the field of sexual relations [12], the norm under consideration may be stipulated in Chapter 18 (Crimes against sexual inviolability and sexual freedom of the person) or Chapter 25 (Crimes against public health and public morals) of the Criminal Code of the Russian Federation.

The definition of the object of incest is also the subject of scientific discussion in states where incest liability has existed for many decades. Thus, in Germany, $\S 173^{1}$ of the Criminal Code in Section 12 "Crimes against civil status, marriage and family" allows some authors claiming that the legal institutions of marriage and family are protected benefits [13].

Other authors also consider a threat to the mental development of a sexual partner (for example, a minor daughter or a brother and a sister in case of incest between them) or a potential risk of genetic damage to

\footnotetext{
${ }^{1} \S 173$. Incest

(1) Whoever engages in sexual relations with a blood relative in the descending line is punished with imprisonment for up to three years or a fine.

(2) Whoever engages in sexual relations with an ascending blood relative shall be punished by imprisonment for up to two years or a fine. This provision also applies if the relations are terminated. Blood brothers and sisters who have sexual relations with each other are punished in the same way.

(3) Descending relatives, brothers and sisters shall not be punished in accordance with this rule if they have not reached the age of 18 at the time of the commission of the act.
}

possible offspring as the basis for classification and criminal liability [14].

However, many modern authors [15] generally doubt the criminal legal legitimization of this norm and require its removal from the criminal law.

This opinion is justified by the fact that, firstly, free sexual self-determination is comprehensively protected by other norms of the Federal Republic of Germany ( $\S \S$ 174, 176, etc.).

Secondly, the ability of the incest rule to pursue unwanted sexual relations within the family and its focus on achieving this goal is doubtful because the incriminated actions are limited exclusively to sexual relations (i.e. penile-vaginal sexual contact). Besides, the existence of established family relations does not matter to the components of $\S 173$.

Thirdly, it is in this special case that the desire to eliminate the potential risk of genetic damage to possible offspring through a composition that criminalizes the creation of abstract danger is very problematic, since such (even abstract) danger is completely excluded in persons who are not capable of childbearing.

Finally, in the modern public sense, it is unacceptable with the help of the criminal law to direct human sexual behavior on the arguments of eugenics. In response to one of the convictions in the incest criminal case, the German Society of Human Genetics issued a statement noting that the existing higher risk that children from incestuous relationships will have genetic diseases cannot justify any legal interference with the couple's "reproductive freedom". In this regard, Pavel Golovnenkov writes that in the end it should be recognized that from the point of view of rational protection of legal interests, the legitimization of $\S 173$ is at least doubtful [14]. It is difficult to disagree with this. However, the arguments for criminalization are as serious as those against. Under such circumstances, it is possible to create an inapplicable corpus delicti for the purpose of preventing and social and legal prevention of blood-related closely related sexual relations that may potentially lead to offspring.

\section{Conclusion}

As a result of the study, the following conclusions were made.

1. Incest has a social danger consisting in the possibility of hereditary pathology and causing harm to the interests of the family and public morals. 
2. The potential danger of incest seems sufficient to establish criminal liability.

3. The rule on incest can be included in the chapter on sexual crimes, the chapter on crimes against the family and minors, or the chapter on crimes against public health and public morals. It seems that such a rule can be formulated as follows: "Incest, i.e. sexual relationship between relatives in direct ascending and descending lines, full blood brothers and sisters and halfsiblings, as a result of which genetic diseases in offspring are possible".

The work was carried out as part of a grant from the President of the Russian Federation for state support of young Russian scientists No. MK-4898.2021.2.

\section{References}

1. A.P. Dyachenko, E.I. Tsymbal, Incest and its criminal evaluation, Criminal Law, 4, 27-32 (2014)

2. S.N. Enikolopov, E.S. Khvostova, Views on incest in the context of different cultures and traditions. Status update on the problem, Psychological science and education, 2, 10-20 (2012)

3. N.M. Parshin, Problems of criminal liability for incest: history and modernity, Society and Law, 2(44), 102106 (2013)

4. B. Sancak, I. Tasdemir, O. Karamustafalioglu, Mother-daughter incest: A brief review of literature and case report, J. Forensic Sci. (2021). DOI: https://doi.org/10.1111/1556-4029.14751.

5. A.H. Bittles, Consanguinity in Context (Cambridge University Press, 2012). Retrieved from: https://scholar.google.com/scholar?cluster $=9203923$ $777437637401 \& \mathrm{hl}=\mathrm{ru} \&$ as $\_$sdt $=0,5$.

6. R.H. Bixler, The multiple meaning of "incest", Journal of Sex Research, 19, 197-201 (1983). DOI: https://doi.org/10.1080/00224498309551180.
7. S.P. Green, Incest. In: The Palgrave Handbook of Applied Ethics and the Criminal Law (L. Alexander and K.K. Ferzan., eds.) (Palgrave-MacMillan, London, 2019) pp. 337-57

8. P. Choate, R. Sharan, The Need to Act: Incest as a Crime Given Low Priority - A View with India as an Example, Social Sciences, 10(4), 142 (2021). DOI: https://doi.org/10.3390/socsci10040142.

9. Yildirim, Ali, Erdal Ozer, Hasan Bozkurt, Sait Ozsoy, Ozgur Enginyurt, Durmus Evcuman, Riza Yilmaz, Yunus E. Kuyucu, Evaluation of social and demographic characteristics of incest cases in a university hospital in Turkey, Medical Science Monitor: International Medical Journal of Experimental and Clinical Research, 20, 693-97 (2014). DOI: 10.12659/MSM.890361.

10. G.E. Andrade, A libertanian critique of incest laws: Philosophical and anthropological perspectives, Human Affairs, 31(2), 139-148 (2021). DOI: https://doi.org/10.1515/humaff-2021-0012.

11. G. Murdock, R. Linton, The common denominator of cultures Ed. The science of man in the world, pp. 65-87 (New York Columbia University Press, 1945)

12. A.A. Bimbinov, Quality of norms on liability for crimes against public morals in the field of sexual behavior of a person, Bulletin of Voronezh State University. Series: Law, 3, 231-239 (2017)

13. NK-StGB / Monika Frommel, 3. Aufl. 2010, StGB $\S$ 173 Rn. 11, 16.

14. P.V. Golovnenkov, Criminal Code of the Federal Republic of Germany. Scientific and practical commentary and translation of the text of the law (University of Potsdam Publishing House, 2021) 492 p.

15. Schönke/Schröder/Lenckner/Bosch, 29. Aufl. 2014, StGB $§ 173$. 